\title{
Alterations in the Gill Filaments and Secondary Lamellae of Cirrhinus mrigala Exposed to "Nuvan," an Organophosphorus Insecticide
}

\author{
Nidhi Srivastava, Usha Kumari, Amita Kumari Rai, Swati Mittal, and Ajay Kumar Mittal \\ Skin Physiology Laboratory, Centre of Advanced Study, Department of Zoology, Banaras Hindu University, Varanasi 221 005, India \\ Correspondence should be addressed to Swati Mittal; drsmittal73@gmail.com
}

Received 30 June 2014; Revised 18 September 2014; Accepted 3 October 2014; Published 27 October 2014

Academic Editor: Victor H. Casco

Copyright @ 2014 Nidhi Srivastava et al. This is an open access article distributed under the Creative Commons Attribution License, which permits unrestricted use, distribution, and reproduction in any medium, provided the original work is properly cited.

\begin{abstract}
The alterations in the epithelium of the gill filaments and the secondary lamellae of the gills of Cirrhinus mrigala, on exposure to "Nuvan," have been explored in the present investigation using light and scanning electron microscopy. The fishes were exposed to two sublethal concentrations, $5 \mathrm{mg} / \mathrm{L}$ and $15 \mathrm{mg} / \mathrm{L}$, of "Nuvan." The changes are more rapid and intensive at higher concentration than at lower concentration, suggesting that the changes are dose dependent. Increase in thickness of epithelium covering secondary lamellae, merger of epithelium of gill filaments and adjacent secondary lamellae, and aneurysm is considered to reduce efficiency of gills for gaseous exchange. A significant decline in the density and area of the mucous goblet cells in the epithelium of the gill filaments and the secondary lamellae of C. mrigala exposed to "Nuvan" could be correlated with excessive loss of the secretory contents of these cells, uncompensated by their production in sufficient quantities. The histopathological changes, in general, take longer time to recover in the fishes exposed to $15 \mathrm{mg} / \mathrm{L}$ than those exposed to $5 \mathrm{mg} / \mathrm{L}$ indicating that the changes in fishes exposed to higher concentration are more severe than those at lower concentration of the insecticide.
\end{abstract}

\section{Introduction}

The use of chemical insecticides is fairly recognized as a cost effective method of controlling the pests and parasites in agriculture and aquaculture practices, but these chemicals are highly toxic to other species in the environment. They produce adverse effects on nontarget aquatic organisms living in areas near agricultural fields [1]. Pesticides often end up in aquatic habitats carried up by wind, rain water, or through uncontrolled waste disposal. Being biodegradable and of short persistence in environment, organophosphorus insecticides are extensively used for the control of pests in agricultural fields, and, therefore, large quantities of these insecticides reach the water bodies [2]. "Nuvan," an organophosphorus insecticide, is released on surface water as it is a commonly used chemotherapeutant in fish farming to eradicate crustacean ectoparasites [3-7] and to treat culture ponds for the eradication of freshwater fish predators prior to the stocking of spawn-fry, fingerlings, or juveniles of carps [8-10].
In fish, gills are the main site of gaseous exchange [1115]. In addition, they are involved in osmoregulation [1619], acid base balance [20-23], and excretion of nitrogenous compounds [24-26]. The complexity and constant contact with the surrounding water make the gill the first target to waterborne pollutants [27]. Several studies have been made in the past on the histological organization and physiology of gills in a variety of fish species under control conditions. Important reviews on the structure of gills in relation to their respiratory function of fish species that have appeared in the literature include those of Hughes (1984) [28], Laurent and Perry (1995) [29], Wilson and Laurent (2002) [30], and Evans et al. (2005) [31]. More recently, Cinar et al. (2009) [15] reported the histology of the gills of the fish Pseudophoxinus antalyae and Tano de la Hoz et al. (2014) [32] reported the surface ultrastructure of the gills of Odontesthes argentinensis.

According to Mallatt (1985) [33], gills are the primary sites of toxic action of many waterborne pollutants and the gill lamellae serve as an interface for ion and gas exchange between the blood and the external medium. Studies on the 
alterations in the gills of fish, induced by organophosphorus insecticides, are very few. These include reports in the gills of fish species Lepomis macrochirus exposed to malathion [34]; Gambusia affinis exposed to malathion [35]; Corydoras paleatus exposed to "Folidol 600," a commercial formulation ofmethyl parathion, [36]; Metynnis roosevelti exposed to methyl parathion [37]; and Cirrhinus mrigala exposed to chlorpyrifos [38]. Nevertheless, studies on the gills of fish, exposed to "Nuvan," an organophosphorus insecticide, have not attracted the attention of workers yet. In addition, a review of the literature reveals that the knowledge of the recovery pattern of histological organization in gills of fish exposed to organophosphate insecticides is still lacking. Therefore, the present study has been designed in order to compare the short-term toxic effect of the insecticide at a lower concentration as well as at higher concentration under controlled laboratory condition. This study may unravel the histopathological as well as the ultrastructural alterations in the gill filaments and the secondary lamellae of C. mrigala exposed to "Nuvan" and assess the recovery pattern of its histological organization using light and scanning electron microscopy.

Cirrhinus mrigala [39] (family Cyprinidae, order Cypriniformes, taxonomic serial number 163679 , retrieved from Integrated Taxonomy Information System, 2008) [40] (common name-mrigal; local name in Hindi-Nain) is an active, herbivorous bottom feeder, extensively cultured in ponds by fish farmers, and constitutes one of the major groups of species preferred for composite fish culture in India.

\section{Materials and Methods}

Live specimens of the fish Cirrhinus mrigala (mean \pm SD standard length, $L_{S} 93 \pm 9 \mathrm{~mm}$, and weight $12.63 \pm 3.05 \mathrm{gm}$ ) were collected from local ponds at Varanasi. The fishes were kept at controlled room temperature $\left(25 \pm 2^{\circ} \mathrm{C}\right)$ in glass aquaria containing water, aerated continuously and were acclimatized with the laboratory conditions for 15 days prior to the commencement of the experiments. The fishes were fed daily with algae and minced yolk of boiled egg, plankton, and commercial fish food, Tokyu brand baby pellets (M.C.T. Aquarium, Import and Export, Changwat Nakhon Pathom, Thailand). Water quality characteristics were determined following APHA, AWWA, and WPCF (1985) [41]. The quality parameters (mean \pm SD) of water used for acclimation in controls and for the preparation of test solution were temperature, $25 \pm 1^{\circ} \mathrm{C}$; dissolved oxygen, $7.43 \pm 0.06 \mathrm{mg} / \mathrm{L}$; $\mathrm{pH}, 7.05 \pm 0.006$; alkalinity, $288 \pm 11.5 \mathrm{ppm}$; and hardness, $170.67 \pm 1.16 \mathrm{mg} / \mathrm{L}$ as $\mathrm{CaCO}_{3}$.

2.1. "Nuvan". The commercial formulation "Nuvan" (Syngenta India Ltd.) was used for the study. It is an organophosphorus emulsifiable concentrate containing dichlorvos $(76.0 \% \mathrm{w} / \mathrm{w})$ as the active ingredient. The inert ingredients include emulsifier $(10.6 \% \mathrm{w} / \mathrm{w})$ and solvent $(13.4 \% \mathrm{w} / \mathrm{w})$. The stock solution was prepared by dissolving "Nuvan" $(100 \mathrm{mg} / \mathrm{L})$ in water and subsequently diluting to final test concentrations.
2.2. Test Concentrations of "Nuvan". The fishes were exposed to the sublethal test concentrations of "Nuvan" using $24 \mathrm{~h}$ renewal bioassay method [41]. The test concentrations of "Nuvan" were selected in order to understand and to compare the short-term toxic effect of the insecticide at a lower concentration $5 \mathrm{mg} / \mathrm{L}$ (i.e., $25 \% 96 \mathrm{~h} \mathrm{LC50}$ value) and at higher concentration $15 \mathrm{mg} / \mathrm{L}$ (i.e., 75\% $96 \mathrm{~h} \mathrm{LC50}$ value). The doses were selected randomly based on the survivability response of the fish.

Fishes exposed to the insecticide (experimental fishes) as well as those without being exposed (control fishes) for different intervals, $4 \mathrm{~h}, 8 \mathrm{~h}, 12 \mathrm{~h}, 1$ day (d), $2 \mathrm{~d}, 3 \mathrm{~d}$, and $4 \mathrm{~d}$, were cold-anesthetized following Mittal and Whitear (1978) [42]. The fishes were kept in water at room temperature $(25 \pm$ $2^{\circ} \mathrm{C}$ ); crushed ice was added to the water gradually, at such a rate that the temperature fell a few degrees every few minutes. At $10 \pm 1^{\circ} \mathrm{C}$ the fishes became immobile and unresponsive to touching or pricking and the fishes were taken out of water without struggle to excise the gills. The fishes were euthanized after sampling. Second pair of gill arches was selected for this study.

2.3. Light Microscopy. At each interval, pieces of these gill arches, from the experimental and control fishes, were excised, rinsed in physiological saline, and then fixed in Aqueous Bouin's fluid [41]. Another group of the fishes exposed to the test concentrations of the insecticide for $96 \mathrm{~h}$ were transferred to freshwater for recovery. These fishes were cold-anesthetized at different intervals of recovery-2 days of recovery ( $2 \mathrm{dr}$ ), $4 \mathrm{dr}, 6 \mathrm{dr}, 8 \mathrm{dr}, 12 \mathrm{dr}$, and $16 \mathrm{dr}$. Pieces of the gills from control as well as experimental fishes were then excised, rinsed in physiological saline, and fixed in Aqueous Bouin's fluid [43]. The tissues were then dehydrated in an ethanol series of ascending concentration, cleared in cedar wood oil, and embedded in paraffin wax (melting point 58$\left.60^{\circ} \mathrm{C}\right)($ E-Merck, India). Serial sections were cut at a thickness of $6 \mu \mathrm{m}$ using a Leica Rotary Microtome (Model RM 2125RT, Leica Mikrosysteme Vertrieb GmbH-DSA, Germany). The sections were mounted on ethanol-cleaned glass slides and were kept in an oven at $37^{\circ} \mathrm{C}$ overnight to dry. Sections were deparaffinized in xylene, hydrated in a descending ethanol series, and stained with Ehrlich's haematoxylin and eosin $(\mathrm{H} / \mathrm{E})$ [44]. The stained sections were dehydrated in an ascending ethanol series, cleared in xylene, and mounted in DPX (Distrene dibutylphalate xylene). Observations were made on a Leitz "Laborlux S" microscope (Ernst Leitz GmbH, Wetzlar, Germany). The results were recorded using a digital camera system Leica DFC 290 (Leica Microsystems Ltd., Germany) on an Intel Pentium D computer (Model dx2280 MT, Hp Compaq, USA).

2.4. Scanning Electron Microscopy. Excised pieces of the gill arch were rinsed in physiological saline, dipped briefly in $0.1 \%$ solution of S-carboxymethyl-L-cysteine to remove mucus [45], and fixed in 3\% glutaraldehyde in $0.1 \mathrm{M}$ sodium cacodylate buffer, at $\mathrm{pH} 7.4$ for $4 \mathrm{~h}$ at $4^{\circ} \mathrm{C}$. Following fixation, the tissues were washed in $0.1 \mathrm{M}$ sodium cacodylate buffer ( $\mathrm{pH}$ 7.4) and dehydrated at $4^{\circ} \mathrm{C}$ with graded ethyl alcohol 
in ascending concentrations. The tissues were then treated with ethyl alcohol and acetone in the ratios $3: 1,1: 1$, and $1: 3$, anhydrous acetone, and dried using a Critical Point Dryer (E3000 series, Quorum Technologies Ltd., UK) with liquid carbon dioxide as the transitional fluid. Critical point-dried tissues, glued to the stubs, were coated with gold using a Sputter Coater (SC7620, Quorum Technologies Ltd., UK) and examined with a Scanning Electron Microscope (EVO LS 10 Zeiss, Germany).

2.5. Statistical Analysis. The area and the density of the mucous goblet cells were measured in AB2.5/PAS (histochemical method for the localization of glycoproteins) stained tissue sections, in which these cells are clearly delineated. Leica Qwin3, an advanced image processing and analysis software (Leica Microsystems, Germany), was used for the measurement of the thickness of the epithelium and the area of different cell types. A combination of a stage micrometer (object micrometer) with scale graduated in units of $1 / 100$ ( 1 division $=0.01 \mathrm{~mm}$ ) and an eyepiece graticule (ocular micrometer) with a square grid (Carl Zeiss, Jena, Germany) was used for the measurement of the density of different cell types. The thickness of the epithelium covering the gill filaments and the secondary lamellae was measured in $\mathrm{H} / \mathrm{E}$ stained cross-sections of the tissues. The statistics was based on the data obtained from ten random microscopic fields for each set of the experiment. Data obtained from three independent sets of experiment were pooled to estimate mean and standard deviation (mean \pm SD) using Microsoft Excel 2007 on an Intel Core 2Duo computer (Model Vostro 1400, Dell, USA).

Statistical comparisons were made between data obtained from control and experimental fish using one-way ANOVA followed by Dunnett post hoc test, through Statistical Package for the Social Sciences (SPSS) for Windows (standard version 11.5) software. $P<0.05$ were accepted as levels of statistical significance.

\section{Results}

In Cirrhinus mrigala, the surfaces of the gill filaments and the secondary lamellae are covered with a mosaic pavement of irregularly polygonal epithelial cells of varied dimensions. The free surfaces of these cells are characterized by the presence of a series of microridges (Figure 1(a)).

The main cellular components of the epithelium of the gill filaments and the secondary lamellae consist of the epithelial cells and the mucous goblet cells. In addition, the eosinophilic granular cells are discernible at intermittent intervals in the epithelium of the gill filaments. The epithelium covering the secondary lamellae, in general, is represented by a superficial layer and a basal layer lying on a thin noncellular basement membrane. The central core of the secondary lamellae consists of blood spaces, separated at regular intervals, by a series of pillar cells (Figure 1(b)). In control fish, the thickness of the epithelium covering the gill filaments is $14.79 \pm$ $5.29 \mu \mathrm{m}$ and is $3.15 \pm 0.87 \mu \mathrm{m}$ on the secondary lamellae (Table 1).
TABLE 1: Thickness of the epithelium, density, and area of mucous goblet cells covering different regions of the gills in Cirrhinus mrigala kept in control.

\begin{tabular}{lccc}
\hline Regions & Thickness $(\mu \mathrm{m})$ & $\begin{array}{c}\text { Mucous goblet cells } \\
\text { Density } \\
(\text { number/mm }\end{array}$ & $\begin{array}{c}\text { Area } \\
\left(\mu \mathrm{m}^{2}\right)\end{array}$ \\
\hline Gill filaments & $14.79 \pm 5.29$ & $1600 \pm 160$ & $14.94 \pm 3.09$ \\
Secondary lamellae & $3.15 \pm 0.87$ & $320 \pm 80$ & $13.10 \pm 1.35$ \\
\hline
\end{tabular}

Values $=$ mean $\pm \mathrm{SD} ; N=3$ fishes.

3.1. Epithelial Cells. The epithelial cells in the epithelium covering the gill filaments, in general, appear wedge shaped in the superficial layer, polygonal in the middle layer, and low columnar, cuboidal, or flattened in the basal layer (Figure 1(b)). The epithelial cells in the epithelium covering the secondary lamellae, in general, are vertically flattened and have centrally placed flattened nuclei (Figure 1(b)).

In the fishes exposed to $15 \mathrm{mg} / \mathrm{L}$ of "Nuvan," the epithelial cells in the superficial layer and the underlying layers of the epithelium of the gill filaments and the secondary lamellae, at $4 \mathrm{~h}$, compared to those of the controls, get hypertrophied and swollen. In the epithelium of the secondary lamellae the free surface of the superficial layer epithelial cells, in general, gets eroded (Figure $1(\mathrm{c})$ ). At $8 \mathrm{~h}$ and $12 \mathrm{~h}$, in general, the epithelium of the gill filaments and the secondary lamellae merges, and at $12 \mathrm{~h}$, in addition, epithelial cells either isolated or in sheets could be observed exfoliated at the surface (Figure $1(\mathrm{~d})$ ). The epithelium shows oedema and appears detached from the underlying cores of blood spaces and pillar cells (Figure $1(\mathrm{~d})$ ). At $1 \mathrm{~d}$, the epithelium shows oedema at frequent intervals and appears detached from the underlying tissues. Further, at intermittent intervals, small islets are observed showing that the epithelium of gill filament is fused with the epithelium of several secondary lamellae (Figures 1(e) and $1(\mathrm{f}))$. At $2 \mathrm{~d}$, the epithelium of the gill filaments merges with the epithelium covering major portion of the secondary lamellae. At infrequent intervals, the core of the secondary lamellae collapses; blood spaces appear ruptured resulting in the accumulation of the blood cells, which could be termed as the aneurysm (Figure $1(\mathrm{~g})$ ). In addition to these changes, the epithelium of the secondary lamellae frequently shows oedema and appears detached from the underlying tissues including blood spaces and pillar cells which constitutes the core of the secondary lamellae (Figures $1(\mathrm{~g})$ and 1(h)). At $3 \mathrm{~d}$ and $4 \mathrm{~d}$, in general, the changes in the epithelium covering the gill filaments and the secondary lamellae appear similar to those observed on $2 \mathrm{~d}$. Nevertheless, oedema and detachment of the epithelium of the secondary lamellae are more pronounced and the aneurysm is frequently observed.

In contrast, the effect on the epithelial cells of the gill filaments and the secondary lamellae in the fishes exposed to $5 \mathrm{mg} / \mathrm{L}$ of "Nuvan" are delayed. The superficial layer epithelial cells in the epithelium of the secondary lamellae and the gill filaments, at $8 \mathrm{~h}$ to $1 \mathrm{~d}$, often appear hypertrophied and swollen. The free surfaces of these cells are frequently observed rounded and bulged at the surface (Figures 2(a) and 2(b)). In addition, epithelial cells are occasionally observed 


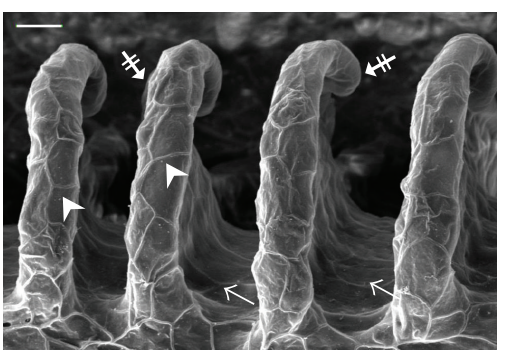

(a)

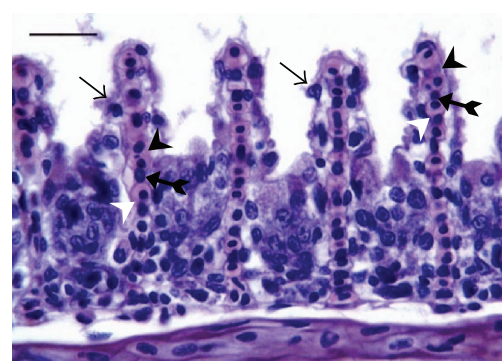

(c)

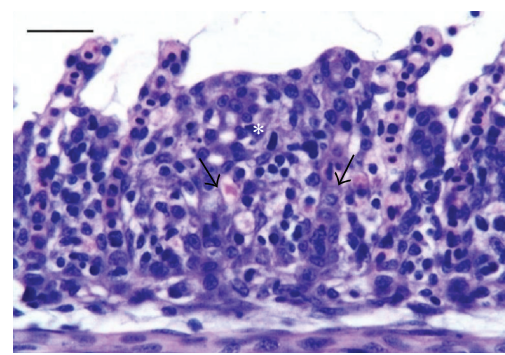

(e)

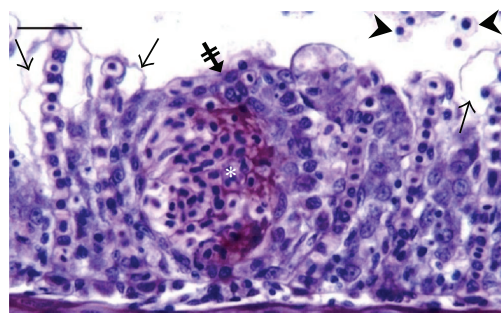

(g)

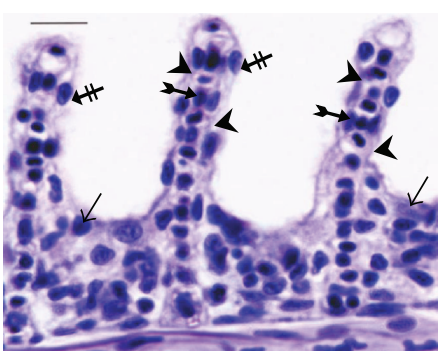

(b)

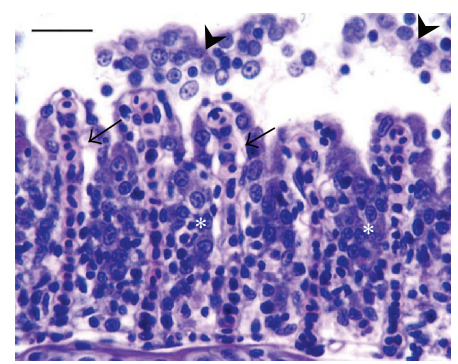

(d)

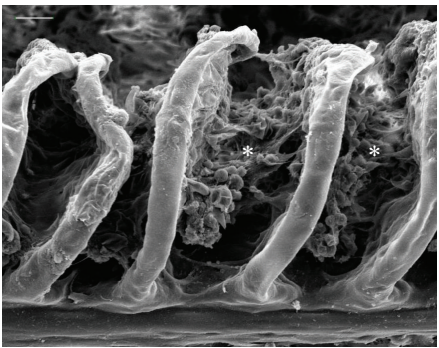

(f)

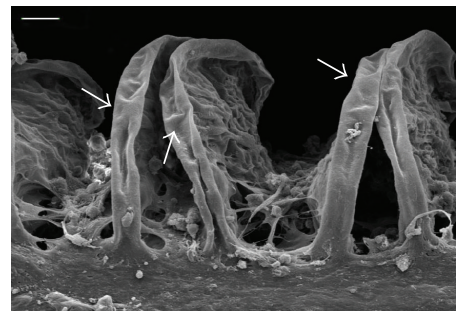

(h)

FIGURE 1: Scanning electron micrograph of the gill filament and secondary lamellae of C. mrigala under control conditions (a) and exposed to $15 \mathrm{mg} / \mathrm{L}$ of "Nuvan" (f, h). Photomicrographs of cross-sections of gills of C. mrigala under control conditions (H/E) (b) and exposed to $15 \mathrm{mg} / \mathrm{L}$ of "Nuvan" (c, d, e, and g). (a) A part of the gill filament (arrows) showing arrangement of the secondary lamellae (barred arrows). Note the boundary of the adjacent epithelial cells is demarcated by microridges (arrow heads). Scale bar $=10 \mu \mathrm{m}$. (b) In gill filament epithelium, superficial layer epithelial cells are wedge shaped in gill filament epithelium (arrow), flattened in secondary lamellae epithelium (barred arrows), and the cores of secondary lamellae consist of pillar cells (winged arrows) in between blood spaces (arrow heads) having blood cells. Scale bar $=10 \mu \mathrm{m}$. (c) Epithelial cell membranes at free surfaces appear eroded (arrows). Note enlarged blood spaces (arrow heads) between pillar cells (winged arrows) $(4 \mathrm{~h}$ ). Scale bar $=20 \mu \mathrm{m}$. (d) Epithelium of gill filament is merged with epithelium of secondary lamellae (asterisks). Epithelium shows oedema and appears detached from the underlying cores of blood spaces and pillar cell (arrows). Sheets of epithelial cells exfoliated at the surface are discernible (arrow heads) $(12 \mathrm{~h})$. Scale bar $=20 \mu \mathrm{m}$. (e) Epithelium of gill filament merges with epithelium of several secondary lamellae forming an islet of interlamellar cell mass (asterisk). Note at intervals blood spaces between pillar cells appear disrupted and are located with difficulty (arrows) (1d). Scale bar $=20 \mu \mathrm{m}$. (f) Adjacent secondary lamellae appear fused due to the formation of interlamellar cell mass (asterisk) (1 d). Scale bar $=10 \mu \mathrm{m}$. (g) An islet of interlamellar cell mass (barred arrow). Blood spaces between pillar cells in the core of the secondary lamellae appear disrupted resulting in aneurysm (asterisk). Note oedema and detachment of epithelium of secondary lamellae (arrows) and exfoliated cells at the surface (arrow heads) ( $2 \mathrm{~d}$ ). Scale bar $=20 \mu \mathrm{m}$. (h) Uplifting and detachment of the epithelium of secondary lamellae (arrows) $(2 \mathrm{~d})$. Scale bar $=10 \mu \mathrm{m}$. 


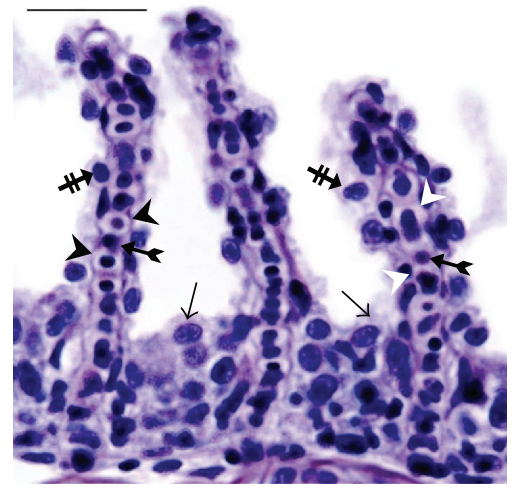

(a)

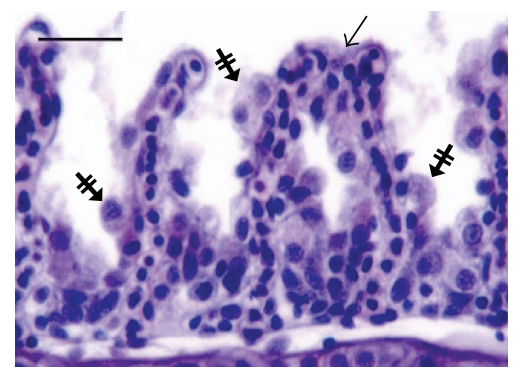

(c)

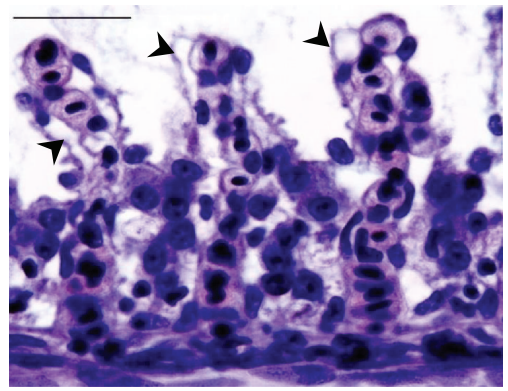

(e)

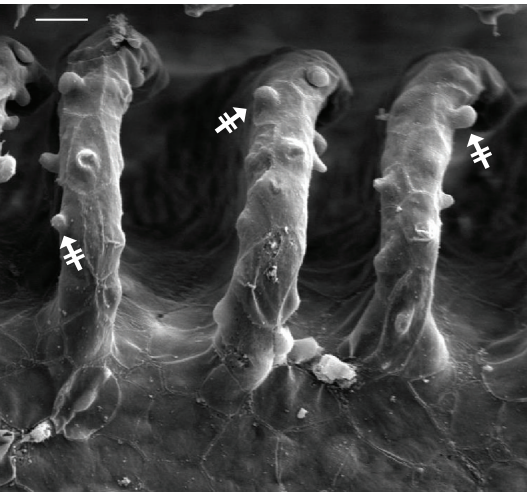

(b)

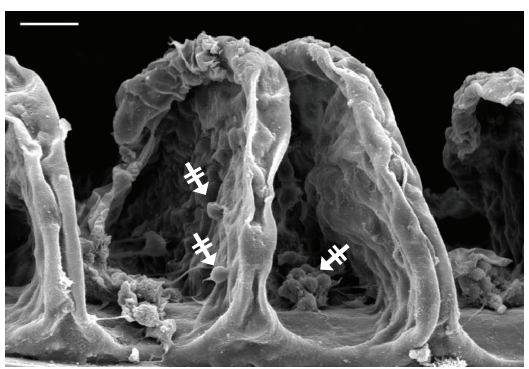

(d)

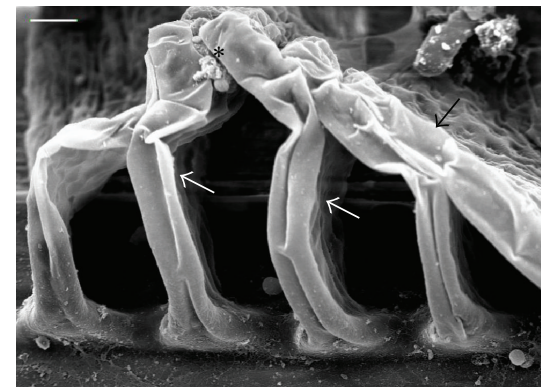

(f)

Figure 2: Photomicrographs of cross-sections (H/E) (a, c, and e) and scanning electron micrographs (b, d, and f) of gills of C. mrigala exposed to $5 \mathrm{mg} / \mathrm{L}$ of "Nuvan." (a) Epithelium of gill filament (arrows) and secondary lamellae (barred arrows) increase in thickness due to hypertrophy of the epithelial cells. Note enlarged blood spaces (arrow heads) between pillar cells (winged arrows) $(12 \mathrm{~h})$. Scale bar $=20 \mu \mathrm{m}$. (b) The free surfaces of the epithelial cells appear rounded and bulged at the surface (barred arrows). (12 h) Scale bar $=10 \mu \mathrm{m}$. (c) Apical ends of adjacent secondary lamellae appear fused (arrow). Epithelial cells in the epithelium of gill filaments and secondary lamellae are greatly hypertrophied and appear bulging (barred arrows) at the surface (1 d). Scale bar $=20 \mu \mathrm{m}$. (d) Epithelial cells in the epithelium of gill filaments and secondary lamellae appear bulged (barred arrows) at the surface $(1 \mathrm{~d})$. Scale bar $=10 \mu \mathrm{m}$. (e) Oedematous swellings in the epithelium covering the secondary lamellae (arrow heads) ( $3 \mathrm{~d}$ ). Scale bar $=20 \mu \mathrm{m}$. (f) Uplifting and detachment of the epithelium of secondary lamellae (arrows). Note the fusion of the apical end of several adjacent secondary lamellae (asterisk) ( $3 \mathrm{~d}$ ). Scale bar $=10 \mu \mathrm{m}$.

exfoliated at the surface. At $1 \mathrm{~d}$, the superficial layer epithelial cells in the epithelium of the secondary lamellae often appear highly hypertrophied and swollen. The free surfaces of these cells are frequently observed rounded and bulged at the surface (Figures 2(c) and 2(d)). At infrequent intervals, the adjacent secondary lamellae come close to each other and the epithelium at their apical ends appears fused with each other (Figure 2(c)). At $2 \mathrm{~d}$, the epithelium of gill filament merges with the epithelium of the secondary lamellae. At $3 \mathrm{~d}$ and $4 \mathrm{~d}$, the epithelium covering the secondary lamellae, at intervals, shows oedematous swellings and appears detached from the underlying tissues (Figures 2(e) and 2(f)). Further, the epithelium of the gill filament merges to a great extent with the epithelium of the secondary lamellae and the apical ends of the adjacent secondary lamellae appear fused (Figure 2(f)).

In the fishes exposed to $15 \mathrm{mg} / \mathrm{L}$ of "Nuvan" for $4 \mathrm{~d}$ and then on their transfer to freshwater, the epithelium of the gill filaments and the secondary lamellae shows a relatively slow recovery than that in the fishes transferred to freshwater after their exposure to $5 \mathrm{mg} / \mathrm{L}$ of the insecticide. At $2 \mathrm{dr}$, the epithelium of the gill filaments, which get merged with the epithelium of the secondary lamellae at $4 \mathrm{~d}$ of exposure to the 


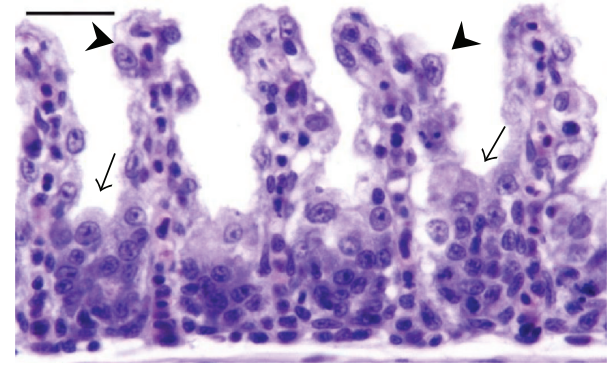

(a)

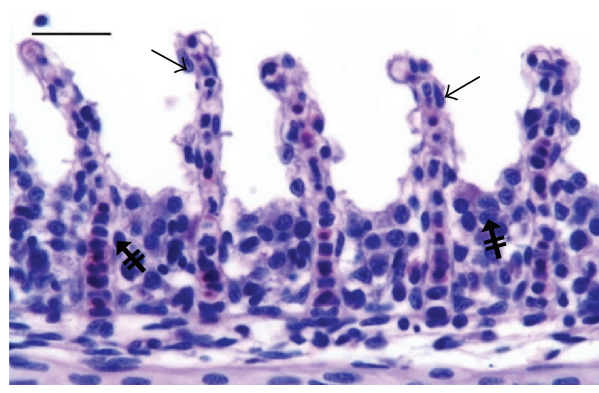

(c)

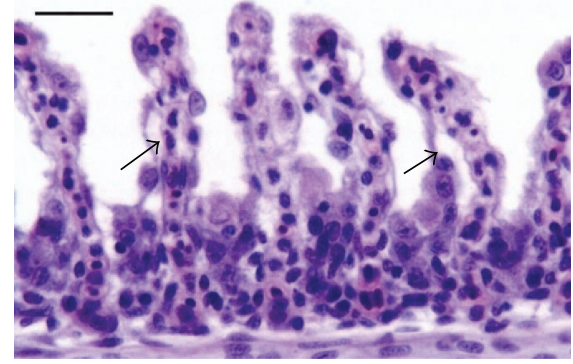

(b)

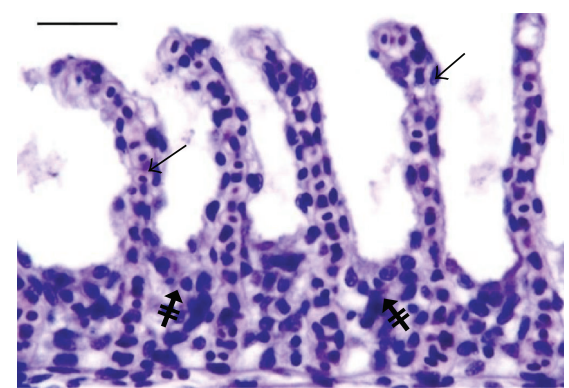

(d)

Figure 3: Photomicrographs of cross-sections of gills of C. mrigala exposed of "Nuvan" for $4 \mathrm{~d}$ and then transferred to freshwater for recovery to $15 \mathrm{mg} / \mathrm{L}(\mathrm{a}-\mathrm{c})$ and to $5 \mathrm{mg} / \mathrm{L}$ (d) (H/E). Scale bar $=20 \mu \mathrm{m}$. (a) Epithelial cells of the epithelia of secondary lamellae (arrow heads) and gill filament (arrows) appear hypertrophied. Major portion of secondary lamellae is not merged with the epithelium of gill filament. Note secondary lamellae appear thick ( $2 \mathrm{dr}$ ). (b) Similar as (a). Epithelium of secondary lamellae at intervals appears detached from the underlying tissues (arrows) (2 dr). (c) Epithelial cells of the epithelia of secondary lamellae (arrows) and gill filament (barred arrows) do not appear hypertrophied. Note secondary lamellae appear slender (6 dr). (d) Epithelial cells of the epithelia of secondary lamellae (arrows) and gill filament (barred arrows) do not appear hypertrophied. Note secondary lamellae appear slender, similar to those of the controls ( $4 \mathrm{dr}$ ).

insecticide, appears retracted. Further, the epithelial cells in the different layers of the epithelium of the gill filaments and the secondary lamellae, in general, appear less hypertrophied. In the secondary lamellae, the detachment of the epithelium from the underlying tissues is less prominent than that at $4 \mathrm{~d}$ of exposure (Figures 3(a) and 3(b)). Further, the epithelial cells exfoliated at the surface are less frequently observed. At subsequent durations, hypertrophy of the epithelial cells in the epithelium of the gill filaments and the secondary lamellae, detachment of the epithelium of the secondary lamellae, and exfoliation of the epithelial cells show a gradual decrease and by $8 \mathrm{dr}$ the epithelium of the gill filaments and the secondary lamellae appears similar to that of the controls (Figure 3(c)). At $5 \mathrm{mg} / \mathrm{L}$, the epithelium of the gill filaments and the secondary lamellae appears similar to that of the controls at $4 \mathrm{dr}$ (Figure 3(d)).

3.2. Thickness of the Epithelium. In the fishes exposed to $15 \mathrm{mg} / \mathrm{L}$ of "Nuvan" for different intervals, the epithelia covering the gill filaments and the secondary lamellae in contrast to those exposed to $5 \mathrm{mg} / \mathrm{L}$, show a sharp increase in their thickness. At these regions, the increase in thickness of the epithelia at different intervals of exposure ( $4 \mathrm{~h}-4 \mathrm{~d})$, compared to that of the controls, is statistically significant (Figures 4(a) and 4(b)). In contrast, in the fishes exposed to $5 \mathrm{mg} / \mathrm{L}$ of "Nuvan" for different intervals, the epithelia covering the gill filaments and the secondary lamellae, in general, show an increase in its thickness which is statistically insignificant up to $1 \mathrm{~d}$ of exposure and thereafter during $2 \mathrm{~d}-$ $4 \mathrm{~d}$ of exposure the epithelium shows a further increase in thickness and is statistically significant (Figures 4(a) and $4(\mathrm{~b})$ ).

The epithelia covering the gill filaments and the secondary lamellae at $2 \mathrm{dr}$ show a decline in their thickness compared to those observed during exposure to "Nuvan" for $2 \mathrm{~d}-4 \mathrm{~d}$ (Figures 4(a) and 4(b)) and appear insignificant. At subsequent durations of recovery, that is, $4 \mathrm{dr}$ to $16 \mathrm{dr}$, the epithelia covering the gill filaments and the secondary lamellae of the fishes show a further decline in their thickness and appear similar to that of controls (Figures 4(a) and $4(\mathrm{~b})$ ).

3.3. Mucous Goblet Cells. The mucous goblet cells in the epithelium covering the gill filaments and the secondary lamellae are rounded or goblet shaped, often confined in the outer layers. However, in the epithelium of the secondary lamellae, these cells could be observed infrequently. Further, the area of each such cell is similar to that in the gill filament epithelium (Table 1).

The mucous goblet cells in the epithelium of gill filaments and the secondary lamellae of the fishes exposed to "Nuvan" at $15 \mathrm{mg} / \mathrm{L}$ as well as $5 \mathrm{mg} / \mathrm{L}$ secrete profusely at the surface and show a significant decline in their density at different intervals from $4 \mathrm{~h}$ to $4 \mathrm{~d}$ (Figures 5(a) and 5(b)). In the fish exposed to "Nuvan" at $15 \mathrm{mg} / \mathrm{L}$, the area of the mucous goblet cells in the epithelium of the gill filaments compared to 


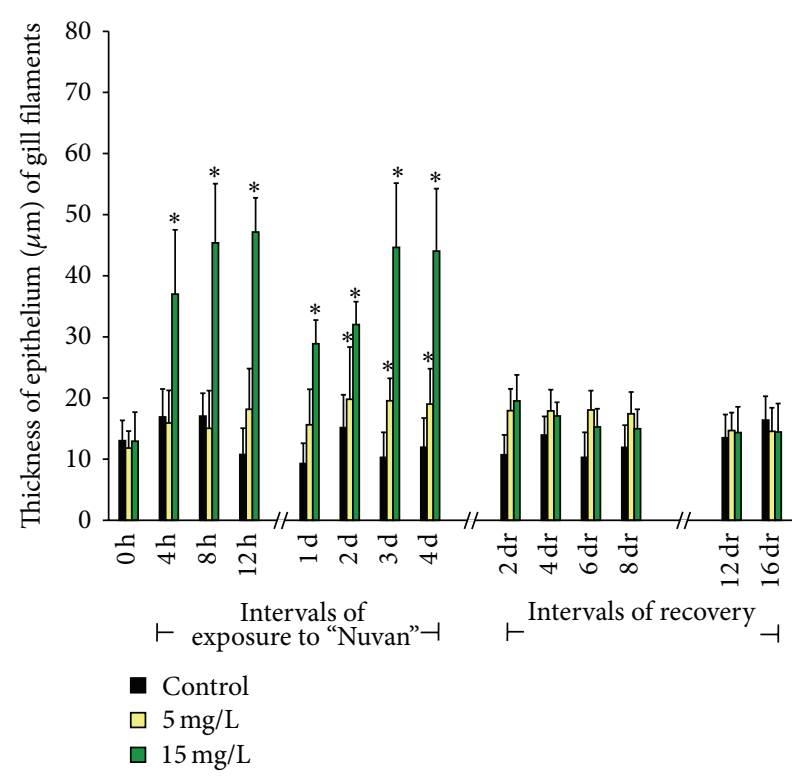

(a)

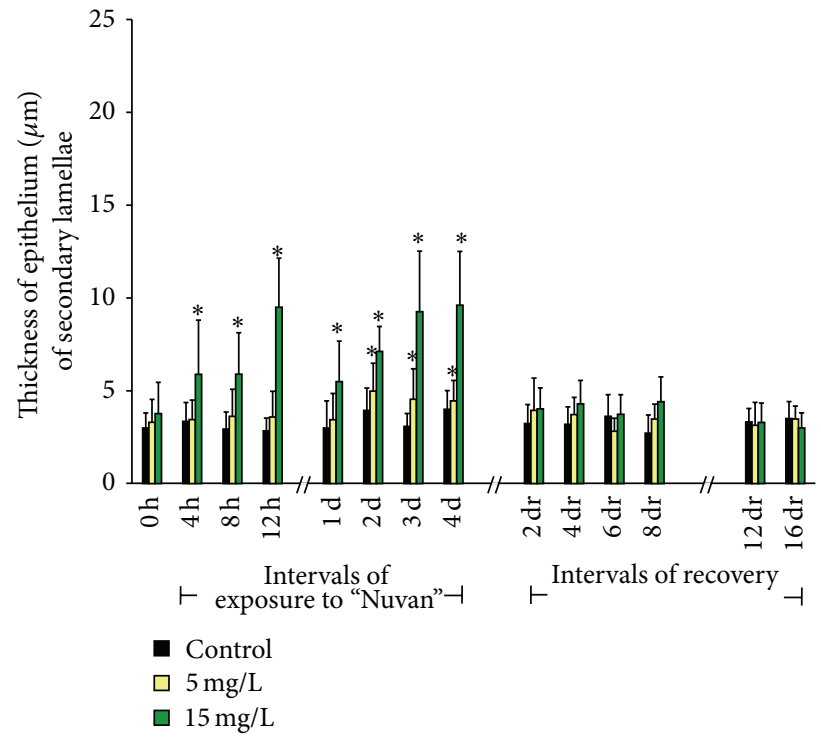

(b)

FIGURE 4: (a) Average thickness of gill filament epithelium ( $\mu \mathrm{m}$; mean $\pm \mathrm{SD}$ ) of $C$. mrigala at different intervals. 0 h: prior to exposure to "Nuvan"; $4 \mathrm{~h}-4 \mathrm{~d}$ : intervals of exposure to $5 \mathrm{mg} / \mathrm{L}$ and $15 \mathrm{mg} / \mathrm{L}$ of "Nuvan"; $2 \mathrm{dr}-16 \mathrm{dr}$ : intervals of recovery after $4 \mathrm{~d}$ exposure to "Nuvan." h: hour; d: day; dr: day of recovery; mg/L: milligram/liter; and asterisks " $*$ " on bars indicate significant difference from control $(P<0.05)$. $n=3$. (b) Average thickness of secondary lamellae epithelium ( $\mu$ m; mean $\pm \mathrm{SD})$ of $C$. mrigala at different intervals. 0 h: prior to exposure to "Nuvan"; $4 \mathrm{~h}-4 \mathrm{~d}$ : intervals of exposure to $5 \mathrm{mg} / \mathrm{L}$ and $15 \mathrm{mg} / \mathrm{L}$ of "Nuvan"; $2 \mathrm{dr}-16 \mathrm{dr}$ : intervals of recovery after $4 \mathrm{~d}$ exposure to "Nuvan." h: hour; d: day; dr: day of recovery; mg/L: milligram/liter; and asterisks "*” on bars indicate significant difference from control $(P<0.05)$. $n=3$.

that of the controls shows insignificant changes at intervals $4 \mathrm{~h}$ to $3 \mathrm{~d}$. However, a significant decrease is observed at $4 \mathrm{~d}$ (Figure 5(c)). In the fish exposed to "Nuvan" at $5 \mathrm{mg} / \mathrm{L}$, the area of the mucous goblet cells in the epithelium of the gill filaments, compared to that of controls, decreases significantly at $4 \mathrm{~h}-12 \mathrm{~h}$ and shows insignificant changes at $1 \mathrm{~d}-3 \mathrm{~d}$. A significant decrease is observed again at $4 \mathrm{~d}$ (Figure 5(c)). At both concentrations, the area of the mucous goblet cells in the epithelium of the secondary lamellae decreases significantly at different intervals from $4 \mathrm{~h}$ to $4 \mathrm{~d}$ (Figure 5(d)).

In the fishes kept for recovery after exposure to "Nuvan" at $15 \mathrm{mg} / \mathrm{L}$, the density of the mucous goblet cells in the epithelium of the gill filaments and the secondary lamellae, compared to that of controls, does not recover and remains significantly decreased at different intervals from $2 \mathrm{dr}$ to $16 \mathrm{dr}$ (Figures 5(a) and 5(b)). The density of the mucous goblet cells in the epithelium of the gill filaments of the fishes transferred to freshwater, after their exposure to "Nuvan" at $5 \mathrm{mg} / \mathrm{L}$ for $4 \mathrm{~d}$, compared to that of controls, recovers and shows insignificant changes within narrow range at $2 \mathrm{dr}$ to $16 \mathrm{dr}$ (Figure 5(a)). In the epithelium of the secondary lamellae, the density of the mucous goblet cells, compared to that of controls, does not recover and remains significantly decreased at different intervals from $2 \mathrm{dr}$ to $16 \mathrm{dr}$ (Figure 5(b)). In the fishes exposed to "Nuvan" at $5 \mathrm{mg} / \mathrm{L}$ or $15 \mathrm{mg} / \mathrm{L}$, the area of the mucous goblet cells, compared to that of controls, remains significantly decreased at $2 \mathrm{dr}$ in the epithelium of the gill filaments (Figure 5(c)) and up to $4 \mathrm{dr}$ in the epithelium of the secondary lamellae (Figure 5(d)). In both regions, it then recovers and shows insignificant changes at different intervals up to $16 \mathrm{dr}$.

\section{Discussion}

The present investigation shows significant changes in the histopathological organization in the gills of Cirrhinus mrigala, exposed to different concentrations of the organophosphate insecticide "Nuvan" for different durations. In general, the alterations are more rapid and intensive at higher concentrations than at lower concentrations, suggesting that the changes are dose dependent.

In Cirrhinus mrigala exposed to "Nuvan," the exfoliation of the epithelial cells at the surface of the secondary lamellae at intermittent intervals suggests that the superficial layer epithelial cells, as a reaction to the treatment, undergo irreversible degenerative changes, terminating in cell death and exfoliation. A significant increase in the thickness of the epithelium covering the secondary lamellae and merger of the epithelium covering the gill filaments and the secondary lamellae could be a result of oedematous swellings and hypertrophy of the epithelial cells. This may increase the respiratory gaseous diffusion distance between water surrounding the gills and blood in blood spaces between pillar cells of the secondary lamellae resulting in a decrease of the efficiency of the exchange of respiratory gases as suggested by Hughes (1966) [11]. Van den Heuvel et al. (2000) [46] suggested that the exposure to chemicals may damage the gills and may 


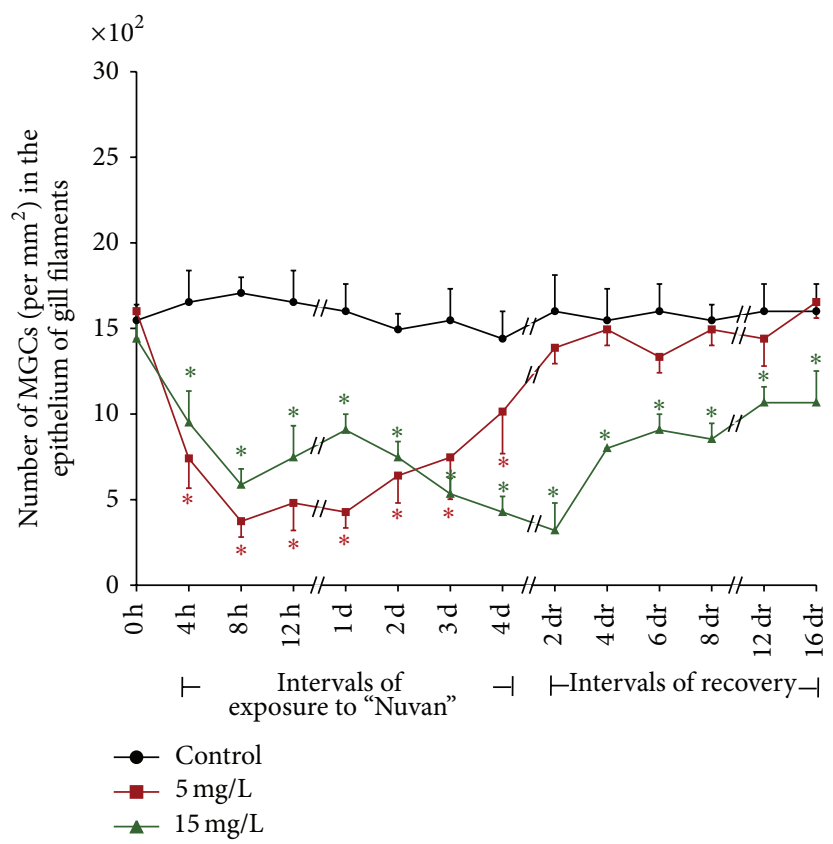

(a)

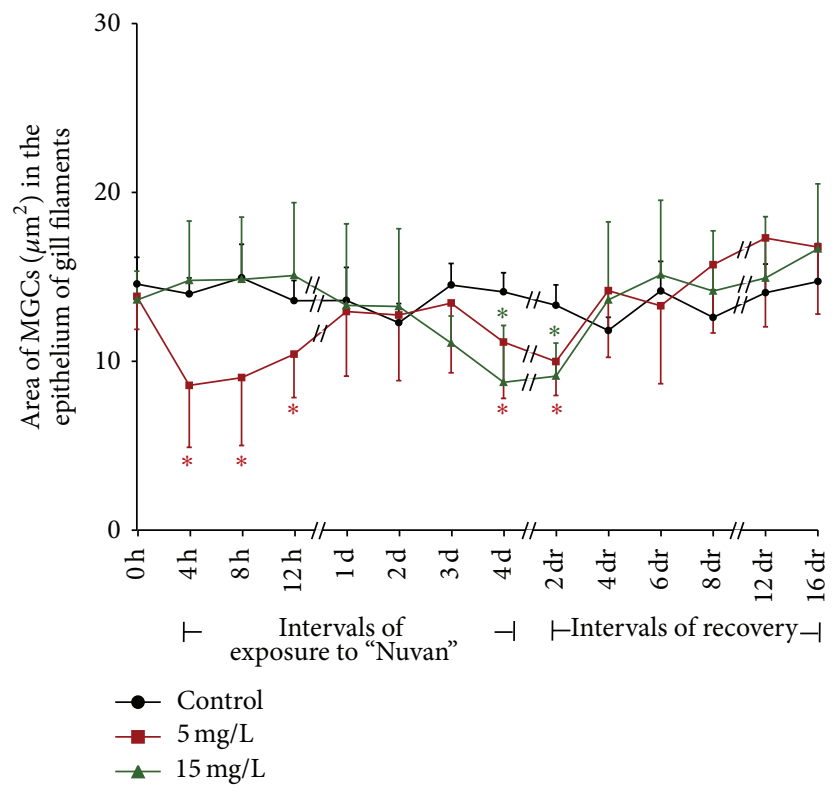

(c)

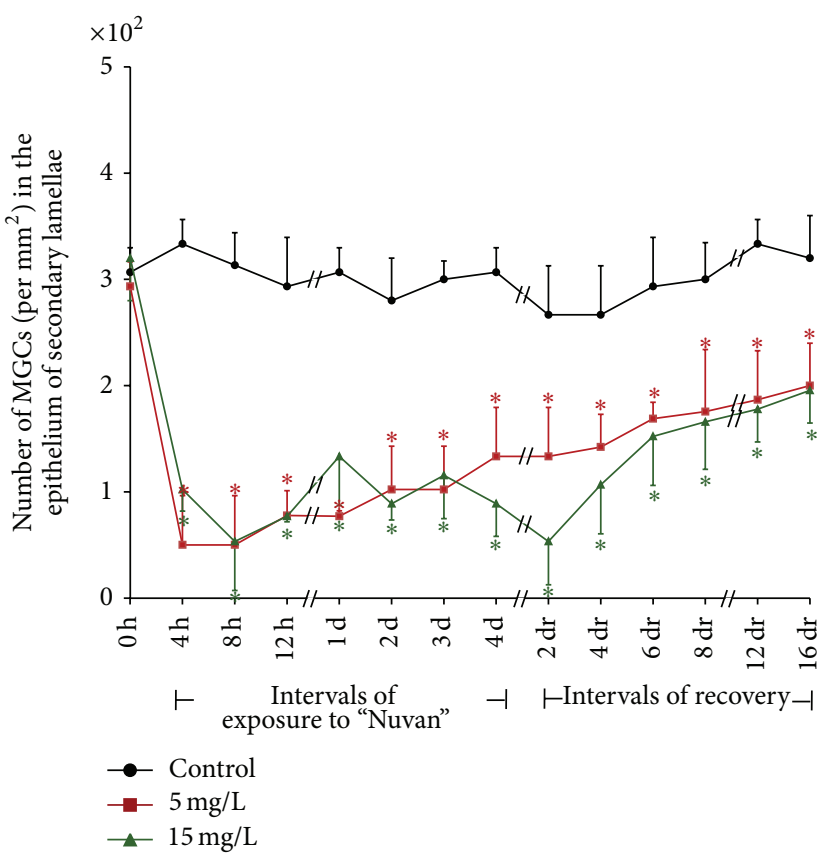

(b)

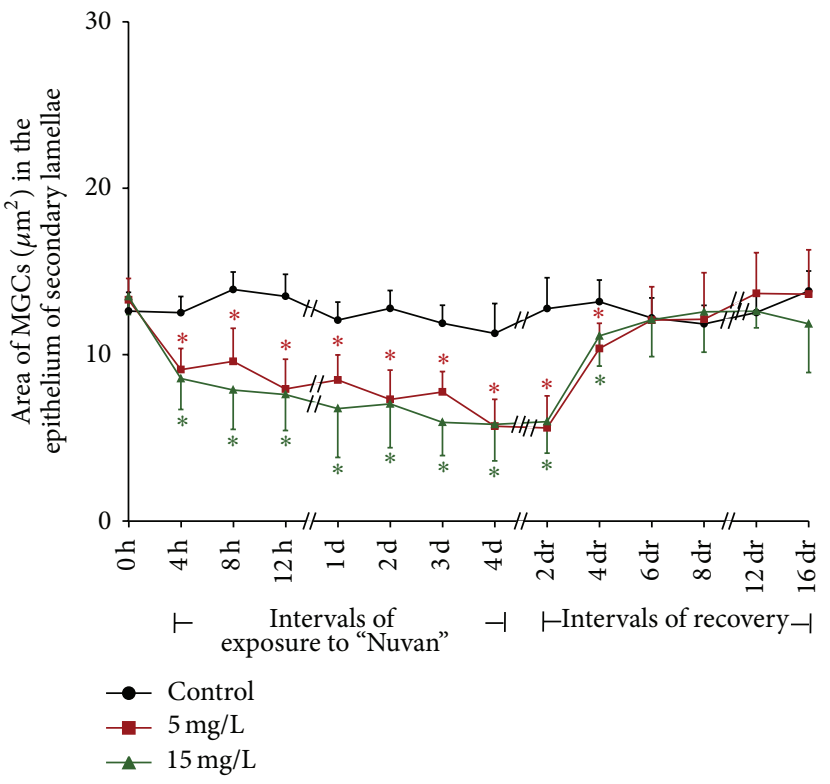

(d)

FIGURE 5: (a) Density of mucous goblet cells (number/mm²; mean $\pm \mathrm{SD}$ ) in the epithelium of the gill filaments of $C$. mrigala at different intervals. 0 h: prior to exposure to "Nuvan"; $4 \mathrm{~h}-4 \mathrm{~d}$ : intervals of exposure to $5 \mathrm{mg} / \mathrm{L}$ and $15 \mathrm{mg} / \mathrm{L}$ of "Nuvan"; $2 \mathrm{dr}-16 \mathrm{dr}$ : intervals of recovery after $4 \mathrm{~d}$ exposure to "Nuvan." h: hour; d: day; dr: day of recovery; mg/L: milligram/liter; and asterisks “*” on points indicate significant difference from control $(P<0.05) . n=3$. (b) Density of mucous goblet cells (number $/ \mathrm{mm}^{2}$; mean $\pm \mathrm{SD}$ ) in the epithelium of the secondary lamellae of C. mrigala at different intervals. 0 h: prior to exposure to "Nuvan"; $4 \mathrm{~h}-4 \mathrm{~d}$ : intervals of exposure to $5 \mathrm{mg} / \mathrm{L}$ and $15 \mathrm{mg} / \mathrm{L}$ of "Nuvan"; $2 \mathrm{dr}-16 \mathrm{dr}$ : intervals of recovery after $4 \mathrm{~d}$ exposure to "Nuvan." h: hour; d: day; dr: day of recovery; mg/L: milligram/liter; and asterisks “*” on points indicate significant difference from control $(P<0.05) . n=3$. (c) Area of mucous goblet cells $\left(\mu \mathrm{m}^{2}\right.$; mean \pm SD) in the epithelium of the gill filaments of C. mrigala at different intervals. 0 h: prior to exposure to "Nuvan"; $4 \mathrm{~h}-4 \mathrm{~d}$ : intervals of exposure to $5 \mathrm{mg} / \mathrm{L}$ and $15 \mathrm{mg} / \mathrm{L}$ of "Nuvan"; 2 dr-16 dr: intervals of recovery after $4 \mathrm{~d}$ exposure to "Nuvan." h: hour; d: day; dr: day of recovery; mg/L: milligram/liter; and asterisks “*” on points indicate significant difference from control $(P<0.05) . n=3$. (d) Area of mucous goblet cells $\left(\mu \mathrm{m}^{2} ;\right.$ mean \pm SD) in the epithelium of the secondary lamellae of $C$. mrigala at different intervals. $0 \mathrm{~h}$ : prior to exposure to "Nuvan"; $4 \mathrm{~h}-4 \mathrm{~d}$ : intervals of exposure to $5 \mathrm{mg} / \mathrm{L}$ and $15 \mathrm{mg} / \mathrm{L}$ of "Nuvan"; $2 \mathrm{dr}-16 \mathrm{dr}$ : intervals of recovery after $4 \mathrm{~d}$ exposure to "Nuvan." h: hour; d: day; dr: day of recovery; mg/L: milligram/liter; and asterisks " $*$ " on points indicate significant difference from control $(P<0.05) . n=3$. 
result in the "leakage" of physiologically important ions out of the fish into the aqueous environment. The thickening of the epithelial layer probably represents an adaptation to overcome this leakage. Hypertrophy of the epithelial cells in different regions of the gills of the exposed fish could also be linked with the inability of the cell to maintain proper ionic balance, which may in turn cause an enhanced osmotic uptake of water by the cells [41]. Organic xenobiotics such as insecticides pass rapidly through the gills to enter the blood stream [47], which facilitates their distribution to the branchial cells and other organs [48]. In view of this, increase in thickness of the blood water barrier in the epithelium covering the secondary lamellae of Cirrhinus mrigala could also be considered to impede the diffusion of the insecticide from the surrounding water medium to the blood stream.

In Cirrhinus mrigala exposed to "Nuvan" at higher concentrations, appearance of aneurysm at an interval of $2 \mathrm{~d}$ and onward could cause the disruption/reduction in gaseous exchange capability and consequently weakening of the fishes. This corroborates with the views of Rudnicki et al. (2009) [49] who reported aneurysm in secondary lamellae of the gills of Piaractus mesopotamicus exposed to Azodrin 400, an organophosphate. Machado and Fanta (2003) [37], in the gills of Metynnis roosevelti exposed to methyl parathion, an organophosphate, reported the collapse of the pillar cells followed by a loss of shape of the erythrocytes that can be considered to indicate osmotic and ionic alterations.

A significant decline in the density and area of the mucous goblet cells in the epithelium of the gill filaments and the secondary lamellae of Cirrhinus mrigala exposed to "Nuvan" at $5 \mathrm{mg} / \mathrm{L}$ and $15 \mathrm{mg} / \mathrm{L}$ at different intervals could be correlated with profuse mucous secretion at the surface as an immediate response to the insecticide. The mucous cells could be efficient in seizing the toxic agent and thus help in the prevention of the entrance of these agents into the gills [27]. Mallat (1985) [33] and Powell et al. (1992) [50] suggested that the mucous layer protects the lamellar surfaces against infectious agents, toxic agents, and particles in suspension. Apparently, rapid exhaustion of the mucous goblet cells, during exposure to "Nuvan" at $5 \mathrm{mg} / \mathrm{L}$ and $15 \mathrm{mg} / \mathrm{L}$ at different intervals, is not compensated by formation of new mucous goblet cells. Wendelaar Bonga (1997) [51] reported that, in gills, the hypersecretion of mucus is often followed by its depletion and the differentiation of new cells as part of a compensatory response to a variety of stressors, in both freshwater and seawater species.

The histopathological changes in the epithelium of the gills such as thickness of the epithelium, merger of the epithelium, and aneurysm and exfoliation of the epithelial cells, in general, take longer time to recover in the fishes exposed to $15 \mathrm{mg} / \mathrm{L}$ than those exposed to $5 \mathrm{mg} / \mathrm{L}$. This indicates that the changes in fishes exposed to higher concentration are more severe than those at lower concentration of the insecticide. Nevertheless, recovery of the epithelium of gills of fish, treated with "Nuvan," on their transfer to freshwater suggests that histopathological reactions to the stress in the epithelium are defence responses in order to withstand the altered environment and to overcome the period of stress. More recently, Velmurugan et al. (2009)
[52] also reported that Clarias gariepinus, treated with lower concentration $(10.05 \mu \mathrm{g} / \mathrm{L})$ of cypermethrin recovered from damages earlier than did their counterparts treated with higher concentrations $(20.10 \mu \mathrm{g} / \mathrm{L})$.

The density and area of the mucous goblet cells in the epithelium of the gill filaments in the fish exposed to $5 \mathrm{mg} / \mathrm{L}$ of the insecticide recover gradually and by $4 \mathrm{dr}$ appear similar to those of controls. In contrast, gradual increase in the density of the mucous goblet cells that, however, remains significantly lower than that of controls even up to $16 \mathrm{dr}$, in the epithelium of the gill filaments of Cirrhinus mrigala exposed to $15 \mathrm{mg} / \mathrm{L}$ and in the epithelium of the secondary lamellae of the fish exposed to both $5 \mathrm{mg} / \mathrm{L}$ and $15 \mathrm{mg} / \mathrm{L}$ of the insecticide suggests that the epithelium in these regions is severely influenced by the toxicity of the insecticide.

In view of the data of the present study, it can be concluded that the histopathological changes in fishes exposed to $15 \mathrm{mg} / \mathrm{L}$ are more severe than those at $5 \mathrm{mg} / \mathrm{L}$ of the "Nuvan." Further, the changes take longer time to recover in the fishes exposed to higher concentration than those exposed to lower concentration. All these results combined together provide new and valuable information and complement other results available in the literature.

\section{Conflict of Interests}

The authors declare that there is no conflict of interests regarding the publication of this paper.

\section{Acknowledgments}

Nidhi Srivastava was supported as a Project Fellow under the Major Research Project (Principal Investigator: Dr. Swati Mittal) sponsored by the University Grants Commission, Government of India. Usha Kumari was supported as Research Associate sponsored by the Council of Scientific and Industrial Research, Government of India.

\section{References}

[1] N. Chakra Reddy and J. Venkateswara Rao, "Biological response of earthworm, Eisenia foetida (Savigny) to an organophosphorous pesticide, profenofos," Ecotoxicology and Environmental Safety, vol. 71, no. 2, pp. 574-582, 2008.

[2] B. Jyothi and G. Narayan, "Certain pesticide-induced carbohydrate metabolic disorders in the serum of freshwater fish Clarias batrachus (Linn.)," Food and Chemical Toxicology, vol. 37, no. 4, pp. 417-421, 1999.

[3] K. Grave, M. Engelstad, and N. E. Søli, "Utilization of dichlorvos and trichlorfon in salmonid farming in Norway during 19811988," Acta Veterinaria Scandinavica, vol. 32, no. 1, pp. 1-7, 1991.

[4] K. Grave, M. Engelstad, N. E. Søli, and E. L. Toverud, "Clinical use of dichlorvos (Nuvan) and trichlorfon (Neguvon) in the treatment of salmon louse, Lepeophtheirus salmonis. Compliance with the recommended treatment procedures," Acta Veterinaria Scandinavica, vol. 32, no. 1, pp. 9-14, 1991.

[5] D. Jackson and M. J. Costello, "Dichlorvos and alternative sealice treatments," in Aquaculture and the Environment, N. De 
Pauw and J. Joyce, Eds., vol. 16, pp. 215-221, Special Publication European Aquaculture Society, 1992.

[6] M. Roth, R. H. Richards, and C. Sommerville, "Current practices in the chemotherapeutic control of sea lice infestations in aquaculture: a review," Journal of Fish Diseases, vol. 16, no. 1, pp. 1-26, 1993.

[7] I. Mladineo, J. Marsic-Lucic, and M. Buzancic, "Toxicity and gross pathology of ivermectin bath treatment in sea bream Sparus aurata, L," Ecotoxicology and Environmental Safety, vol. 63, no. 3, pp. 438-442, 2006.

[8] S. K. Konar, "Field experiments on the eradication of predaceous insects by the insecticide DDVP," Indian Journal of Fisheries, vol. 11, pp. 689-698, 1964.

[9] U. S. Srivastava and S. K. Konar, "Fishery management with the help of O, O dimethyl-2, 2-dichlorovinyl phosphate, a new insecticide," in Proceedings of the NAST 34th Annual Scientific Meeting Highlights Water as an Important Resource, pp. 31-32, National Academy of Sciences, 1965.

[10] U. S. Srivastava and S. K. Konar, "DDVP as a selective toxicant for the control of fishes and insects," The Progressive FishCulturist, vol. 28, no. 4, pp. 335-338, 1966.

[11] G. M. Hughes, "The dimensions of fish gills in relation to their function., Journal of Experimental Biology, vol. 45, no. 1, pp. 177-195, 1966.

[12] G. M. Hughes, "An introduction to the study of gills," in Gills, D. F. Houlihan, J. C. Rankin, and T. J. Shuttleworth, Eds., pp. 1-24, Cambridge University Press, Cambridge, UK, 1982.

[13] K. R. Olson, "Vascular anatomy of the fish gill," Journal of Experimental Zoology, vol. 293, no. 3, pp. 214-231, 2002.

[14] A. Mauceri, M. C. Fossi, C. Leonzio et al., "Stress factors in the gills of Liza aurata (Perciformes, Mugilidae) living in polluted environments," Italian Journal of Zoology, vol. 72, no. 4, pp. 285292, 2005.

[15] K. Cinar, A. Aksoy, Y. Emre, and R. N. Aşti, “The histology and histochemical aspects of gills of the flower fish, Pseudophoxinus antalyae," Veterinary Research Communications, vol. 33, no. 5, pp. 453-460, 2009.

[16] R. J. Gonzales and D. G. McDonald, "The relationship between oxygen consumption and ion loss in a freshwater fish," The Journal of Experimental Biology, vol. 163, pp. 317-332, 1992.

[17] G. Flik and P. M. Verbost, "Calcium transport in fish gills and intestine," The Journal of Experimental Biology, vol. 184, pp. 1729, 1993.

[18] S. Romão, C. A. Freire, and E. Fanta, "Ionic regulation and $\mathrm{Na}, \mathrm{K}-\mathrm{ATPase}$ activity in gills and kidney of the aglomerular Antarctic fish Notothenia neglecta upon exposure to seawater dilution," Journal of Fish Biology, vol. 55, pp. 119-130, 2001.

[19] P. M. Verbost, T. J. M. Schoenmakers, G. Flik, and S. E. Wendelaar Bonga, "Kinetics of ATP and $\mathrm{Na}^{+}$-gradient driven $\mathrm{Ca}^{+2}$ transport in basolateral membranes from gills of freshwaterand seawater-adapted tilapia," Journal of Experimental Biology, vol. 186, pp. 95-108, 1994.

[20] F. H. Epstein, P. Silva, and G. Kormanik, "Role of Na-K-ATPase in chloride cell function," The American Journal of Physiology, vol. 238, no. 3, pp. R246-R250, 1980.

[21] D. H. Evans, J. B. Claiborne, L. Farmer, C. Mallery, and E. J. Krasny, "Fish gill ionic transport: methods and models," Biol. Bull, vol. 163, no. 1, pp. 108-130, 1982.

[22] D. G. McDonald, C. M. Wood, R. G. Rhem, M. E. Mueller, D. R. Mount, and H. L. Bergman, "Nature and time course of acclimation to aluminium in juvenile brook trout (Salvelinus fontinalis). I. Physiology," Canadian Journal of Fisheries and Aquatic Sciences, vol. 48, pp. 2006-2015, 1991.

[23] G. G. Goss, S. F. Perry, C. M. Wood, and P. Laurent, "Mechanisms of ion and acid-base regulation at the gills of freshwater fish," Journal of Experimental Zoology, vol. 263, no. 2, pp. 143159, 1992.

[24] L. Goldstein, "Gill nitrogen excretion," in Gills, pp. 193-206, Cambridge University Press, 1982.

[25] D. H. Evans and J. N. Cameron, "Gill ammonia transport," Journal of Experimental Zoology, vol. 239, pp. 17-23, 1986.

[26] M. D. Sayer and J. Davenport, "The relative importance of the gills to ammonia and urea excretion in five seawater and one freshwater teleost species," Journal of Fish Biology, vol. 31, no. 4, pp. 561-570, 1987.

[27] S. F. Perry and P. Laurent, "Environmental effects on fish gill structure and function," in Fish Ecophysiology, J. C. Rankin and F. B. Jensen, Eds., vol. 9 of Chapman \& Hall Fish and Fisheries Series, pp. 231-264, Springer, London, UK, 1993.

[28] G. M. Hughes, "General anatomy of the gills," in Fish Physiology, W. S. Hoar and D. J. Randall, Eds., vol. 10, part A, pp. 1-72, Academic Press, New York, NY, USA, 1984.

[29] P. Laurent and S. F. Perry, "Morphological basis of acid-base and ion regulation in fish," in Advances in Systemic Regulation: AcidBase Regulation, Ion Transfer and Metabolism, N. Heisler, Ed., pp. 91-118, Springer, Berlin, Germany, 1995.

[30] J. M. Wilson and P. Laurent, "Fish gill morphology: inside out," Journal of Experimental Zoology, vol. 293, no. 3, pp. 192-213, 2002.

[31] D. H. Evans, P. M. Piermarini, and K. P. Choe, "The multifunctional fish gill: dominant site of gas exchange, osmoregulation, acid-base regulation, and excretion of nitrogenous waste," Physiological Reviews, vol. 85, no. 1, pp. 97-177, 2005.

[32] M. F. Tano de la Hoz, A. M. García, M. G. Castro, and A. O. Díaz, "Histochemical and scanning electron microscopic approaches to gills in juveniles of Odontesthes argentinensis (Actinopterygii, Atherinopsidae)," International Journal of Aquatic Science, vol. 5, pp. 154-166, 2014.

[33] J. Mallatt, "Fish gill structural changes induced by toxicants and other irritants: a statistical review," Canadian Journal of Fisheries and Aquatic Sciences, vol. 42, no. 4, pp. 630-648, 1985.

[34] C. Richmonds and H. M. Dutta, "Histopathological changes induced by malathion in the gills of bluegill Lepomis macrochirus," Bulletin of Environmental Contamination and Toxicology, vol. 43, no. 1, pp. 123-130, 1989.

[35] E. I. Cengiz and E. Ünlü, "Histopathology of gills in mosquitofish, Gambusia affinis after long-term exposure to sublethal concentrations of malathion," Journal of Environmental Science and Health-Part B Pesticides, Food Contaminants, and Agricultural Wastes, vol. 38, no. 5, pp. 581-589, 2003.

[36] E. Fanta, F. S. Rios, S. Romão, A. C. C. Vianna, and S. Freiberger, "Histopathology of the fish Corydoras paleatus contaminated with sublethal levels of organophosphorus in water and food," Ecotoxicology and Environmental Safety, vol. 54, no. 2, pp. 119130, 2003.

[37] M. R. Machado and E. Fanta, "Effects of the organophosphorus methyl parathion on the branchial epithelium of a freshwater fish Metynnis roosevelt," Brazilian Archives of Biology and Technology, vol. 46, no. 3, pp. 361-372, 2003.

[38] K. S. Tilak, K. Veeraiah, and D. K. Rao, "The effect of Chlorpyrifos, an organophosphate in acetyl cholinesterase activity in freshwater fishes," Journal of Environmental Biology, vol. 26, no. 1, pp. 73-77, 2005. 
[39] B. Hamilton, An Introduction to the Study of Fishes, Adam and Charles Black, Edinburgh, UK, 1822.

[40] Integrated Taxonomy Information System, Cirrhinus mrigala: Taxonomic Serial number 163679, Integrated Taxonomy Information System, 2008, http://www.itis.gov.

[41] APHA, AWWA, and WPCF, Standard Methods for the Examination of Water and Waste Water, American Public Health Association, Washington, DC, USA, 16th edition, 1985.

[42] A. K. Mittal and M. Whitear, "A note on cold anaesthesia of poikilotherms," Journal of Fish Biology, vol. 13, no. 4, pp. 519520, 1978.

[43] P. Bouin, Phenomenes Cytologique Anoramaux dans. 1 Histogenes, Nancy, France, 1897.

[44] P. Ehrlich, "Hematoxylinlosung," Zeitschrift für Wissenschaftliche Mikroskopie und Mikroskopische Technik, vol. 3, p. 150, 1886.

[45] M. Whitear and R. M. Moate, "Microanatomy of taste buds in the dogfish, Scyliorhinus canicula," Journal of Submicroscopic Cytology \& Pathology, vol. 26, no. 3, pp. 357-367, 1994.

[46] M. R. van den Heuvel, M. Power, J. Richards, M. MacKinnon, and D. G. Dixon, "Disease and gill lesions in yellow perch (Perca flavescens) exposed to oil sands mining-associated waters," Ecotoxicology and Environmental Safety, vol. 46, no. 3, pp. 334341, 2000.

[47] J. C. Rankin, R. M. Stagg, and L. Bolis, "Effect of pollutant on gills," in Gills, D. F. Houlihan, J. C. Rankin, and T. J. Shuttleworth, Eds., SEB Seminar Series no.16, pp. 207-219, Cambridge University Press, Cambridge, Mass, USA, 1983.

[48] H. M. Dutta, J. S. D. Munshi, P. K. Roy et al., "Effect of diazinon on marcophages of bluegill sunfish, Lepomis macrochirus: a cytochemical evaluation," Experimental Biology Online, vol. 2, no. 17, pp. 1-11, 1997.

[49] C. A. M. Rudnicki, G. C. Melo, L. Donatti, H. G. Kawall, and E. Fanta, "Gills of juvenile fish Piaractus mesopotamicus as histological biomarkers for experimental sub-lethal contamination with the organophosphorus Azodrin 400," Brazilian Archives of Biology and Technology, vol. 52, no. 6, pp. 1431-1441, 2009.

[50] M. D. Powell, H. A. Briand, G. M. Wright, and J. F. Burka, "Ultrastructural localisation of acid phosphatase in intestinal eosinophilic granule cells (EGC) of rainbow trout (Oncorhynchus mykiss) following degranulation with capsaicin," Histology and Histopathology, vol. 7, no. 2, pp. 301-305, 1992.

[51] S. E. Wendelaar Bonga, "The stress response in fish," Physiological Reviews, vol. 77, no. 3, pp. 591-625, 1997.

[52] B. Velmurugan, T. Mathews, and E. I. Cengiz, "Histopathological effects of cypermethrin on gill, liver and kidney of fresh water fish Clarias gariepinus (Burchell, 1822), and recovery after exposure," Environmental Technology, vol. 30, no. 13, pp. 14531460, 2009. 

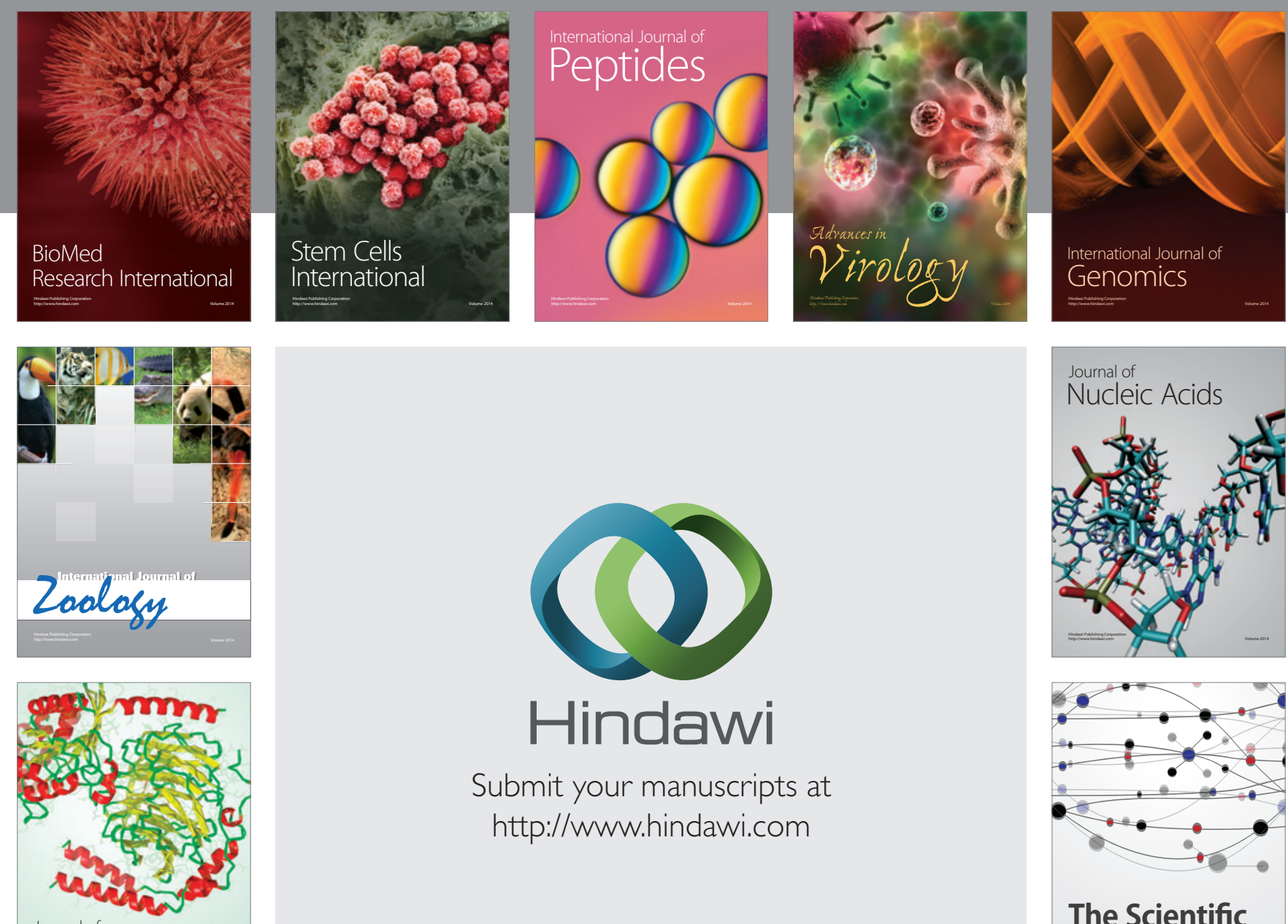

Submit your manuscripts at

http://www.hindawi.com

Journal of
Signal Transduction
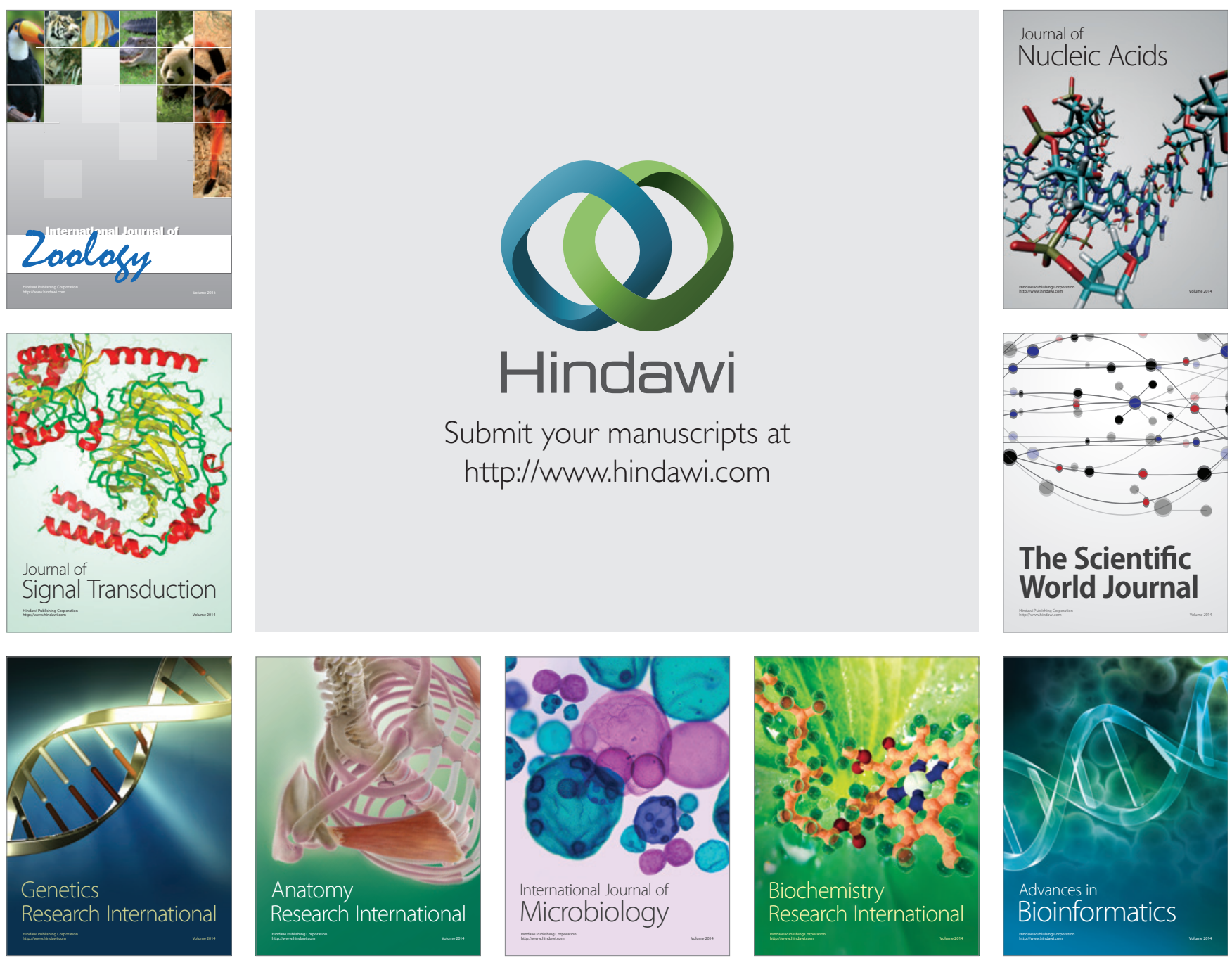

The Scientific World Journal
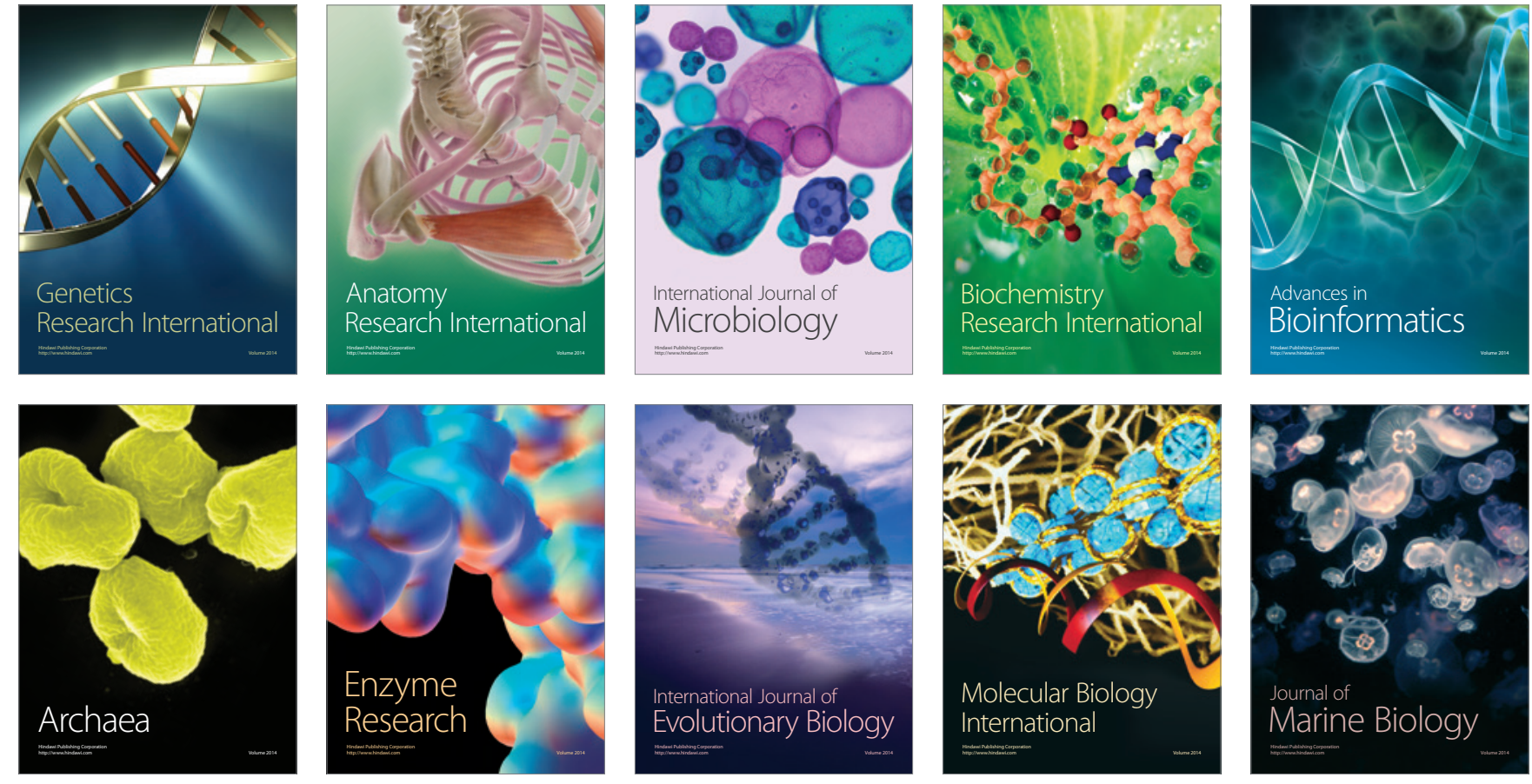